\title{
Comparison between Specific and Multiplex Reverse Transcription-Polymerase Chain Reaction for Detection of Hepatitis A Virus, Poliovirus and Rotavirus in Experimentally Seeded Oysters
}

\author{
C Coelho/ $/{ }^{++}$, CEB Vinatea $/{ }^{++}$, AP Heinert $/{ }^{+++}$, CMO Simões, CRM Barardi $/{ }^{+}$ \\ Laboratório de Virologia Aplicada, Departamento de Microbiologia e Parasitologia, Departamento de Ciências Farmacêuticas, \\ Universidade Federal de Santa Catarina, Campus Universitário Trindade, 88040-900 Florianópolis, SC, Brasil \\ *Departamento de Farmácia, CCS, Universidade do Vale de Itajaí, Itajaí SC, Brasil
}

\begin{abstract}
Outbreaks of gastroenteritis have occurred among consumers of raw or undercooked shellfish harvested from faecally polluted waters. A multiplex reverse transcription-polymerase chain reaction (RT-PCR) was applied for the simultaneous detection of hepatitis A virus (HAV), poliovirus (PV) and simian rotavirus (RV-SA11) and compared with specific primers for each genome sequence. Three amplified DNA products representing HAV (192 bp), PV (394 $b p)$ and $R V(278 \mathrm{bp})$ were identified when positive controls were used. However, when tested on experimentally contaminated raw oysters, this method was not able to detect the three viruses simultaneously. This is probably due to the low concentration of viral RNAs present in oyster extract which were partially lost during the extracts preparation.
\end{abstract}

Key words: oysters - multiplex reverse transcription-polymerase chain reaction - poliovirus - rotavirus - hepatitis A virus

The contamination of water sources including the ocean water and shellfish by pathogenic microorganisms is a worldwide public health concern. Shellfish are readily contaminated with pathogens present in water containing sewage due to the concentrating effect of filter feeding. In order to establish the sanitary quality of shellfish, total and fecal coliform acceptable indexes for water and absence of Salmonella and Staphylococcus coagulase positives for mollusks are nowadays accepted as criteria to guarantee its safety. However, contamination of ocean water and shellfish by enteric viruses, such as hepatitis A virus (HAV), poliovirus (PV), rotavirus (RV), calicivirus, adenovirus and others, has led to waterborne outbreaks of viral diseases (Lees 2000) and it is very important to include the search for these viruses during the sanitary monitoring of aquatic environments. According to Croci et al. (1999) the mollusks body can protect the virus from natural environmental heating and confirming the protective effect of the mollusk meat in relation to virus stability. After replication in the intestinal tract or in the liver (HAV) these viruses are excreted in high amount in the feces

Financial support by Brazilian Mariculture Linkage Program through Canadian International Cooperation Agency.

${ }^{+}$Corresponding author. Fax: +55-48-331.9258. E-mail: ccb1crb@ccb.ufsc.br

${ }^{++}$Master student fellows from Coordenadoria de Apoio a Pesquisa e Ensino Superior; ${ }^{++}$Pibic/CNPq fellowship

Received 30 October 2002

Accepted 9 April 2003
( $10^{6}$ to $10^{10}$ virus particles/g) and can be dispersed in the environment by non-treated sewage (Muniain-Mujika et al. 2002). The first outbreak of HAV has been documented in Sweden in 1955, where 629 cases were associated with the consumption of raw oysters (Roos 1956). Since then many outbreaks worldwide have been associated with the consumption of mollusks (Lees 2000). Compared to other shellfish-borne infectious diseases, the hepatitis disease requires a longer incubation for the symptoms to appear, resulting in fewer opportunities for timely detection of an outbreak and obtaining or accessing the implicated shellfish (Mullendore et al. 2001, Coelho et al. 2003). The Norwalk-like viruses (NLVs) are also considered a major cause of acute nonbacterial gastroenteritis in children and adults, especially associated with important cases of foodborne gastroenteritis associated with the ingestion of contaminated water, food and oysters (Iritani et al. 2000, Carol Shieh et al. 2000).

Rotaviruses represent $80 \%$ of recognized viral etiologies, and 140 million cases of diarrhea per year worldwide. Structurally, rotaviruses belong to the naked class of viruses. These are generally more environmentally resistant than enveloped viruses (Gerba et al. 1996). They are commonly found in waste water and in addition can be both concentrated and transmitted by shellfish. Thus, the environment constitutes a significant reservoir for this virus. They have been implicated in outbreaks of waterborne gastroenteritis in many countries. The stability of human rotaviruses in environmental waters, and their resistance to physico-chemical treatment processes in sewage treatment plants may facilitate their transmission. In addition, their presence in drinking water, sea water and shellfish has been described (Carol Shieh et al. 2000). In 
the case of enteroviruses, the fecal contamination by oral polioviruses vaccine (OPV)-derived PV detected in aerosol from waste water plants could potentially also be the source of virus contamination for humans. Contamination of natural waters with OPV-derived polioviruses might also allow the viruses to disseminate and contaminate large areas. So the poliovirus detection in marine environment can serve as good indicator of fecal pollution (Muscillo et al. 1997). Molecular methods for detecting enteric viruses are faster and more accurate when compared with infectivity tests performed with in vitro cell culture methods (Green \& Lewis 1999). This is especially true when detecting important shellfish-borne viruses for which no infectivity tests are available, e.g. HAV virus contamination in oysters. This study describes the development of a method to simultaneously concentrate and purify different enteric viruses from oysters (Crassostrea gigas) using a multiplex reverse transcription-polymerase chain reaction (RT-PCR). This method was compared with specific protocols for each one of the three viruses (PV, HAV and RV) used as models.

HAV-cytophatic strain HM 175 was grown and assayed in FRhK-4 cells, a continuous line of fetal rhesus kidney-derived cells (Cromeans et al. 1987). For virus titration the indirect immunofluorescence test, described by Barardi et al. (1998) was used with minor modifications (Barardi et al. 1999). PV type 2 (PV2) was propagated in VERO cells (an established line of African green monkey kidney cells) and assayed for infectivity by the plaque assay technique (Sobsey et al. 1978). Simian rotavirus SA11 (group A, serotype G3) was propagated and assayed by indirect immunofluorescence in MA104 cells, a continuous line of fetal rhesus kidney cells. Infected fluid was titrated by indirect immunofluorescence assay as described by Barardi et al. (1998) using $5 \mu \mathrm{g} / \mathrm{ml}$ of trypsin in the maintenance medium. Oysters $(C$. gigas $)$ were obtained from a cultivated system oyster farm in Florianopolis Island, state of Santa Catarina, Brazil. Oyster shells were scrubbed with a stiff brush in running potable water (ca. $0.7 \mathrm{ppm}$ free chlorine). Shell surfaces were coated with a $70 \%$ ethanol solution and left to air dry for $30 \mathrm{~min}$ at room temperature in a biological safety cabinet. Shells were opened at the hinge with an autoclaved oyster knife. In each experiment, samples were individually inoculated with $600 \mu \mathrm{l}$ of each infected cell culture supernatant corresponding to $6 \times 10^{4} \mathrm{ffu}$ of HAV, $1.8 \times 10^{7} \mathrm{ffu}$ of RV and $6 \times$ $10^{6} \mathrm{pfu}$ of PV in three points of the visceral area (gastrointestinal tract) (Barardi et al. 1999). After $30 \mathrm{~min}$ at room temperature, an oyster extract was prepared (see below). Negative controls consisted of non-seeded oysters from the same source. The following method for extraction of virus from oysters extracts was used for the subsequent RT-PCR assay (Barardi et al. 1999 with minor modifications): the flesh of two oysters (10-20 g tissue) was transferred to a sterile Schott ${ }^{\circledR}$ bottle containing 100 $\mathrm{ml}$ of pre-chilled (ice bucket) $10 \%(\mathrm{v} / \mathrm{v})$ tryptose phosphate broth (TPB) $(100 \%$ TPB contains $20 \mathrm{~g}$ tryptose, $2 \mathrm{~g}$ glucose, $5 \mathrm{~g} \mathrm{NaCl}$ and $2.5 \mathrm{Na}_{2} \mathrm{HPO}_{4}, \mathrm{pH} 9.0$ ) prepared in $0.05 \mathrm{M}$ glycine ( $\mathrm{pH}$ adjusted to 9.0 using $2 \mathrm{~N} \mathrm{NaOH}$ ). Tissues were then homogenized with a shaft blender (UltraTurrax T-25 Ika ${ }^{\circledR}$ ) at 24,000 rpm for $30 \mathrm{sec}$. The resulting homogenate was placed in a $50 \mathrm{ml}$ centrifuge tube, shaken at $250 \mathrm{rpm}$ for $30 \mathrm{~min}$ at $22^{\circ} \mathrm{C}$, and centrifuged at 10,000 $\mathrm{X} g$ for $30 \mathrm{~min}$ at $4^{\circ} \mathrm{C}$ (Refrigerated Centrifuge ALC International - PK 121R Monzeze, MI, Italy). The pellet was discarded and the $\mathrm{pH}$ of supernatant was adjusted to 7.5 using $2 \mathrm{M} \mathrm{HCl}$. According Traore et al. (1998) polyethylene glycol solution (PEG 6000) $(50 \%, \mathrm{w} / \mathrm{v})$ prepared in $10 \%$ TPB was added to a final concentration of $8 \%(\mathrm{w} / \mathrm{v})$. The mixture was stirred for $2 \mathrm{~h}$ at $4^{\circ} \mathrm{C}$, and centrifuged at $10,000 \mathrm{X} \mathrm{g}$ for $20 \mathrm{~min}$ at $4^{\circ} \mathrm{C}$. The supernatant was discarded and the pellet resuspended in $5 \mathrm{ml}$ of $0.15 \mathrm{M}$ $\mathrm{Na}_{2} \mathrm{HPO}_{4}, \mathrm{pH}$ 9.0. The resulting material was then sonicated at high power twice for $30 \mathrm{sec}(60$-Sonic Dismembrator-Fisher Scientific, Pittsburgh, PA, USA) and transferred to a centrifuge tube. The $\mathrm{pH}$ readjusted to 7.4 using $2 \mathrm{M} \mathrm{HCl}$. For viral RNA isolation, $500 \mu \mathrm{l}$ of oysters extract were used. For previous purification, an equal volume of trichlorotrifluoroethane (Aldrich) was added to each aqueous oyster extract, and the suspensions centrifuged at $6,000 \mathrm{X} \mathrm{g}$ in a microcentrifuge (Eppendorf $®$ ) for $5 \mathrm{~min}$ at room temperature. Next, the aqueous phase was transferred to another tube. Tris- $\mathrm{HCl}(\mathrm{pH} 7.5)$, EDTA, SDS and proteinase $\mathrm{K}$ were added at final concentrations of $10 \mathrm{mM}, 5 \mathrm{mM}, 0.5 \%$ (w/v) and $400 \mu \mathrm{g} / \mathrm{ml}$, respectively. Samples were then incubated at $37^{\circ} \mathrm{C}$ for $30 \mathrm{~min}$. Cetyltrimethylammonium bromide (CTAB) and $\mathrm{NaCl}$ were added to final concentrations of $1.3 \%(\mathrm{w} / \mathrm{v})$ and $0.52 \mathrm{M}$, respectively, and samples incubated at $56^{\circ} \mathrm{C}$ for $30 \mathrm{~min}$. Samples were subsequently extracted twice with an equal volume of phenol-chloroform-isoamyl alcohol (25:24:1). The aqueous phase was transferred to another microtube and an equal volume of chloroform added. The aqueous phase was then precipitated in 3 vol of chilled $100 \%$ ethanol at $-20^{\circ} \mathrm{C}$. Resulting pellets were washed with chilled $70 \%$ (v/v) ethanol, suspended in $500 \mu 1$ of DEPC treated water (Gibco-BRL), and stored at $-80^{\circ} \mathrm{C}$ for RT-PCR assays. The RT of RNA followed by genomic amplification (RT-PCR), was performed by three methods: (a) cDNA triplex (pool from three RNAs) and PCR triplex (pool of the primers of HAV, RV and PV); (b) cDNA triplex (pool from three RNAs) and PCR specific for each individual virus; (c) cDNA specific (RNAs from each virus in separate) and PCR specific (Table).

RT-PCR triplex: reverse transcription reaction $-3 \mu 1$ of each RNA were denatured by heating at $99^{\circ} \mathrm{C}$ for $5 \mathrm{~min}$ and added to the reaction mix containing 50 pmoles of random primers (Gibco-BRL), 100 pmoles of END9, 50 $\mathrm{mM}$ Tris-HCl pH 8.4, $75 \mathrm{mM} \mathrm{KCl}_{2}, 3 \mathrm{mM} \mathrm{MgCl}, 0.5 \mathrm{mM}$ of dNTPs; $10 \mathrm{mM}$ DDT and 40 U of MLV-RT (Gibco$\mathrm{BRL}$ ). The reverse transcription of viral RNA was performed at $37^{\circ} \mathrm{C}$ for $90 \mathrm{~min}$. The total volume of cDNA was added to $45 \mu 1$ of PCR Super Mix ${ }^{T M}$ (Gibco-BRL). This commercial reaction mix contains $22 \mathrm{mM}$ Tris- $\mathrm{HCl}, \mathrm{pH} 8.4$, $55 \mathrm{mM} \mathrm{KCl}, 1.65 \mathrm{mM} \mathrm{MgCl}_{2}, 0.22 \mathrm{mM}$ each dNTP and 22 units/ml Taq DNA polymerase additional $\mathrm{MgCl}_{2}$ was added to the reaction mix to achieve a final concentration of $3 \mathrm{mM}$; 100 pmoles of each primer (HAV, RV and PV) were added. PCR amplification was carried out for an initial denaturation step of $95^{\circ} \mathrm{C}$ for 2 min followed by 40 cycles of $95^{\circ} \mathrm{C}$ for $1 \mathrm{~min}, 55^{\circ} \mathrm{C}$ for $1 \mathrm{~min}$ and $72^{\circ} \mathrm{C}$ for $1 \mathrm{~min}$, and a final $7 \mathrm{~min}$ incubation at $72^{\circ} \mathrm{C}$. 
TABLE

Summary of multiplex and specific reverse transcription-polymerase chain reaction (RT-PCR) procedure for hepatitis A virus $(\mathrm{HAV})$, rotavirus $(\mathrm{RV})$ and poliovirus $(\mathrm{PV})$ concerning utilized primers

\begin{tabular}{llll}
\hline RT-PCR & cDNA & PCR & PCR product \\
\hline Triplex & Random primers + END 9 & 3 pairs of specific primers & $192 \mathrm{bp}+278 \mathrm{bp}+394 \mathrm{bp}$ \\
HAV & HAV + RV +PV & $192 \mathrm{bp}$ \\
RV & Primer HAVC-R & HAVC-R + HAVC-L & $278 \mathrm{bp}$ \\
PV & Random primers + END 9 & Rota 785 + END 9 & $394 \mathrm{bp}$ \\
\hline
\end{tabular}

bp: base pair

Specific RT-PCR - The reaction mix for RT-PCR was performed as described above except for the primers (specific for each virus). For HAV, the 192-base pair (bp) PCR amplicon corresponds to the genomic region of VP1 and VP3 junction (Mullendore et al. 2001) HAVC-R: 5'CTCCAGAATCATCTCAAC-3' and HAVC-L: 5'CAGCACATCAGAAAGGTGAG-3'. For PV, 5'non-coding region-polio-R: 5' ACGGACACCCAAAGTA-3'C and Polio-L: 5'-AGCACTTCTGTTTCCC-3' primers corresponding to a $394 \mathrm{bp}$ PCR amplicon were used (Atmar et al. 1993). For RV, coding region of the external glycoprotein VP7- End 9: 5'-GGTCACATCATACAATTCT AATCTAAG-3' and Rota785: 5'-TTCGAAATTGTAA GAAATTAG-3', a 278 bp DNA amplicon (Tsai et al. 1994) were used. The RT-PCR was performed with negative controls (non-seeded oysters), viral RNA purified from virus infected cells (HAV, RV and PV) and RNAs isolated from virus seeded oysters (SO). Primers concentration as well as PCR program were the same as described above for the multiplex reaction. PCR products were analyzed by electrophoresis in $10 \%(\mathrm{w} / \mathrm{v})$ polyacrylamide gels. The gels were stained with ethidium bromide at $0.5 \mu \mathrm{g} / \mathrm{ml}$, and visualized under UV light.

Molecular detection by application of PCR for HAV, rotaviruses and enteroviruses, when correctly used, provides reliable data about the presence of these viruses in the environment. Virus identification in shellfish has never been easy, partly because of inefficient virus recovery and natural PCR inhibitors in shellfish (Mullendore et al. 2001). The technique requires extensive sample processing to concentrate low virus number usually found in shellfish, and to remove inhibitory substances before the amplification reaction. In the present study a rapid, efficient and more economic method for the simultaneous detection of three clinically important viruses (HAV, PV, and $\mathrm{RV}$ ) in oysters was tested. Its efficiency was compared with classical RT-PCR protocol specific for each one of these viruses. SO were processed by an absorption-elution-precipitation protocol to concentrate and purify intact viruses. The multiplex RT-PCR protocol followed in the present paper was already used by Tsai et al. (1994) for viral detection in water (sewage and ocean) and by Rosenfield and Jaykus (1999) for purified food-borne virus suspensions. However, it was never used for virus detection in contaminated mollusks. Fig. 1 shows three distinct PCR products representing HAV (192 bp), RV (278

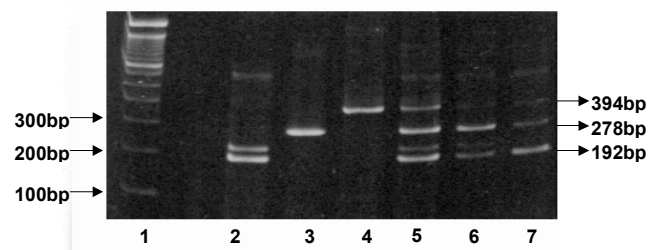

Fig 1: triplex reverse transcription-polymerase chain reaction (RT-PCR), for individual and simultaneous detection of hepatitis A virus (HAV), rotavirus (RV) and poliovirus using controls RNA extracted from infected cell supernatants; 1 - molecular marker: 100 base pair ladder; 2, 3, 4: HAV, RV and PV respectively; 5, 6, 7: triplex RT-PCR $(8,5$ and $3 \mu 1$ of cDNA respectively).

bp) and PV (394 bp), and demonstrated that the triplex RTPCR was efficient to detect the three viruses individually (lanes 2, 3 and 4) and simultaneously (lanes 5, 6, and 7) when positive controls (RNA isolated from infected cell supernatants) were used. Comparisons of sensitivities of viruses detection by triplex protocol were performed with three different volumes of cDNA added on PCR reaction $(8,5$, and $3 \mu \mathrm{l})$. This investigation indicated that a sharper band of HAV was seen when a smaller volume $(3 \mu \mathrm{l})$ of cDNA was used for PCR. Fig. 2 shows the comparison between triplex and specific protocols for detection of HAV, RV and PV on experimentally seeded oysters. Lanes 3, 4 and 5 show specific RT and PCR for HAV, RV, and PV, respectively. Lane 6 shows triplex RT-PCR for HAV+RV+PV and lanes 7, 8, and 9 show cDNA triplex X specific PCR for HAV, RV, and PV, respectively. For oyster extracts the multiplex reaction was not able to detect the three viruses at the same time. Individual protocols worked better in the three cases. When the three RNAs were mixed together in the same tube of reaction the residual RT-PCR inhibitors were possibly increased and consequently the sensitivity was decreased. This failure could also be explained by a possible association of virus particles with solids in an insoluble pellet that could decrease PCR efficiency when the three primers were added simultaneously (Traore et al. 1998, Shieh et al. 1999). Lane 8 shows a clear band for RV using triplex cDNA and specific PCR protocols respectively. This can be explained because End 9 primer (rotavirus specific) + random primer were used during cDNA reaction with triplex protocol. In addition, 


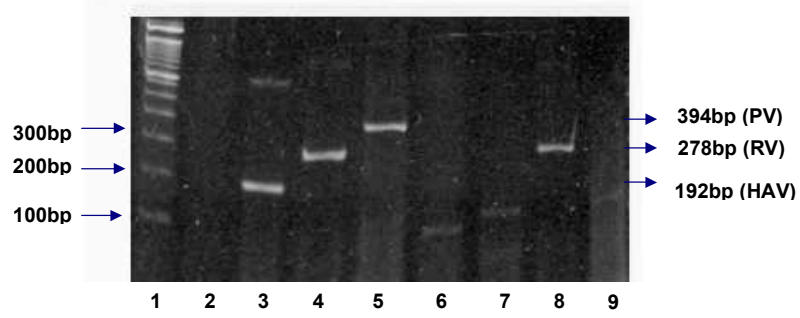

Fig 2: comparison between triplex and specific reverse transcription-polymerase chain reaction for hepatitis A virus (HAV), rotavirus (RV) and poliovirus (PV) detection in experimentally seeded oysters; 1 - molecular marker: 100 base pair ladder; 2 - negative control; 3, 4, 5: HAV, RV and PV respectively; 6 - triplex RT-PCR $\mathrm{HAV}+\mathrm{RV}+\mathrm{PV} ; 7,8,9$ - triplex cDNA X specific PCR for HAV, RV, $\mathrm{PV}$ respectively.

RV has a double stranded RNA genome, more resistant to nucleases than hepatitis $\mathrm{A}$ and polioviruses. In conclusion, the multiplex RT-PCR was not efficient to detect $\mathrm{HAV}, \mathrm{RV}$, and PV simultaneously in artificially SO. However, this study showed that the same RT-PCR program can be sucessfully used for the three virus if specific primers are added in each reaction. This can reduce time, costs and facilitate the use of this methodology for the routine analysis of oysters. Our laboratory is now investigating new protocols to introduce adenoviruses and NLVs detection in cultivated oysters. Some authors had indicate the use of human adenoviruses as a molecular index of the presence of human viruses in general environment and shellfish (Muniain-Mujika et al. 2002). Moreover, the NLVs have been found as the primary etiologic agents (52\%) among reported cases of infectious diseases associated with shellfish consumption (Carol Shieh et al. 2000).

\section{ACKNOWLEGMENTS}

To Dr James J Smith for his review of, and comments on this manuscript.

\section{REFERENCES}

Atmar RL, Metcalf TG, Neill FH, Estes, MK 1993. Detection of enteric viruses in oysters by using polymerase chain reaction. Appl Environ Microbiol 59: 631-635.

Barardi CRM, Emslie KR, Vesey G, Williams KL 1998. Development of a rapid and sensitive quantitative assay for rotavirus based on flow cytometry. J Virol Meth 74: 31-38.

Barardi CRM, Yip H, Emslie KR, Vesey G, Shanker SR, Williams KL 1999. Flow cytometry and RT-PCR for rotavirus detection in artificially seeded oyster meat. Int $J$ Food Microbiol 49: 9-18.

Carol Shieh Y-S, Monroe SS, Fankhauser RL, Langlois GW, Burkhardt III W, Baric RS 2000. Detection of Norwalk-like virus in shellfish implicated in illness. J Infect Dis 181:360366.

Coelho C, Heinert AP, Simões CMO, Barardi CRM 2003. Hepatitis A virus dectection in oysters (Crassostrea gigas) in Santa Catarina state, Brazil, by reverse transcription-polymerase chain reaction. J Food Prot 66: 507-511.

Croci L, De Medici D, Morace G, Fiore A, Scalfaro C, Beneduce F, Toti L 1999. Detection of hepatitis A virus in shellfish by nested reverse transcription-PCR. Int J Food Microbiol 48: 67-71.

Cromeans T, Sobsey MD, Fields HA 1987. Development of a plaque assay for a cytophatic, rapidly replicating isolate of hepatitis A virus. J Med Virol 22: 45-56.

Gerba CP, Rose JB, Haas CN, Crabtree KD 1996. Waterborne rotavirus: a risk assessment. Water Res 30: 29-30.

Green DH, Lewis GD 1999. Comparative detection of enteric viruses in wastewaters, sediments and oysters by reverse transcription PCR and cell culture. Water Res 33: 11951200.

Iritani N, Seto Y, Haruki K, Kimura M, Ayata M, Ogura H 2000. Major change in the predominant type of "Norwalklike viruses" in outbreaks of acute nonbacterial gastroenteritis in Osaka city, Japan, between April 1996 and March 1999. J Clin Microbiol 38: 2649-2654.

Lees D 2000. Viruses and bivalve shellfish. Int J Food Microbiol 59: 81-116.

Mullendore JL, Sobsey MD, Shieh YSC 2001. Improved methods for the recovery of hepatitis A virus from oysters. $J$ Virol Meth 94: 25-35.

Muniain-Mujika J, Girones R, Tofino-Quesada G, Calvo M, Lucena F 2002. Depuration dynamics of viruses in shellfish. J Food Microbiol 77: 125-133.

Muscillo M, La Rosa G, Carducci A, Cantiani L, Marianelli C 1997. Molecular analysis of poliovirus 3 isolated from aerosol generated by a waste water treatment plant. Water Res 31:3125-3131.

Roos R 1956. Hepatitis epidemic conveyed by oysters. Svenska Lakartidningen 53: 989-1003.

Rosenfield SI, Jaykus LA 1999. A multiplex transcription polymerase chain reaction method for detection of foodborne viruses. J Food Prot 62: 1210-1214.

Shieh YSC, Calci KR, Baric RS 1999. A method to detect low levels of enteric viruses in contaminated oysters. Appl Environ Microbiol 65: 4709-4714.

Sobsey MD, Carrick RJ, Jensen HR 1978. Improved methods for detecting enteric viruses in oysters. Appl Environ Microbiol 36: 121-130.

Traore O, Arnal C, Mignotte B, Maul A, Laveran H, Billaudel S, Schwartzbrod L 1998. Reverse transcriptase PCR detection of astrovirus, hepatitis A virus, and poliovirus in experimentally contaminated mussels: comparison of several extraction and concentration methods. Appl Environ Microbiol 64: 3118-3122.

Tsai Y, Tran B, Sangermano LR, Palmer CJ 1994. Detection of poliovirus, hepatitis A virus, and rotavirus from sewage and ocean water by triplex reverse transcriptase PCR. Appl Environ Microbiol 60: 2400-2407. 